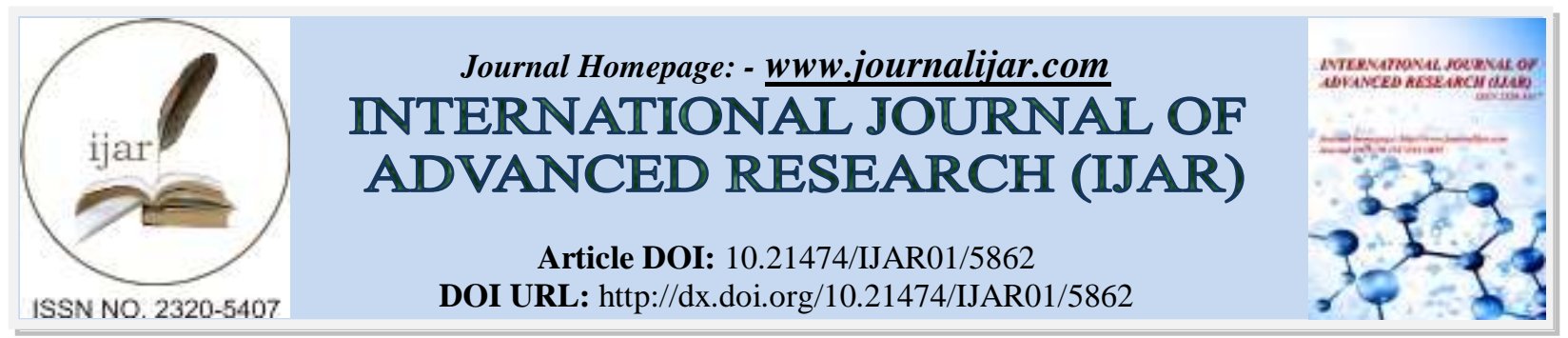

RESEARCH ARTICLE

\title{
GIANT CELL TUMOUR IN DORSAL SPINE.
}

Dr. Arun Kumar Rao ${ }^{1}$, Dr. Aniket Mendhe ${ }^{2}$, Dr. Tejas Daghe ${ }^{2}$ and Tushar Manohar Rothe ${ }^{3}$.

1. Professor and Head of Department of Orthopaedics, MIMSR Medical College Latur, India.

2. P.G. Student, Department of Orthopaedics, MIMSR Medical College Latur, India.

3. Senior Lecturer Department of Oral and Maxillofacial Surgery, Dr. RRK Dental College, Akola, India.

\section{Manuscript Info}

Manuscript History

Received: 14 September 2017

Final Accepted: 16 October 2017

Published: November 2017

Key words:-

OPG, Malocclusion, lateral

cephalogram.

\section{Abstract}

A 27 year old male patient presented with low back pain, after six month he presented with bilateral lower limb power loss with bowel bladder involvement. On clinical examination he was having local tenderness over mid thoracic level around T7-T8. On MRI it was found that the lytic lesion over T7 body along with cord compression. Decompression was done surgically. Microscopically it was confirmed that the lesion was Giant Cell Tumor. Giant Cell Tumor on dorsal vertebral body is an uncommon entity and total en bloc excision is difficult. Therefore, the treatment strategy is not well-defined. We discussing in brief about incidence, presentation and various treatment modalities available for spinal Giant Cell Tumor.

Copy Right, IJAR, 2017,. All rights reserved.

\section{Introduction:-}

Giant cell tumor (GCT) of bone is a rare neoplasm that accounts for approximately 5\% of all primary bone tumors in adults. GCT most frequently occurs at the end of long bones, and the sacrum is the fourth most common site, accounting for between 1.7-8.2\% of cases. Giant cell tumor also occurs in the mobile spine, but this location accounts for only $2-4 \%$ of cases. In all locations, the neoplasm occurs most commonly between the ages of 20-45 years of age, and it affects males and females with equal frequency. It is locally aggressive, and tumor recurrence is frequently seen after intralesional or incomplete excision.Totalspondylectomy with appropriate reconstruction for preservation of spinal integrity is the treatment of choice. Radiation therapy can be given in cases of subtotal resection.

\section{Case Report:-}

A 27 yrs old male patient farmer by occupation came to orthopaedics opd in rural and tertiary care hospital with C/O back pain since last 10 days on January.He started pain in lower back since last 10 days. Pain was sudden on onset and increased on walking and doing work. He was treated conservatively for back pain with analgesics and muscle relaxant (aceclofenac + thiocholchicoside). He was relieved of pain.He started feeling of heaviness in his B/L lower limb in mid of April. He came to OPD in june with paraplegia and bowel bladder involvement and undergone local examination where he was found to have local tenderness over T7 vertebral level, hypoesthesia below T7 level and b/l lower limb weakness with bowl bladder involvement. He undergone MRI scanning of the Thoracic spine and found to have lytic lesion and destruction of T7 vertebral body with cord compression at T7 level. He undergone Contrast MRI to confirm the lytic lesion which was S/O Koch's affection at T7 level.He undergone operative procedure for decompression through transthoracic approach and decompression bone graft and fixation was done with titanium plate. 
He came for follow up after one month there was no power improvement. He undergone mri again which was s/o of cord compression at same level. He undergone operative procedure again through posterior approach and decompression done. Tissue sample taken and sent for histopath examination which was s/o gaint cells tumor with reactive osteoid formation, differential diagnosis gaint cell tumor with aneurismal bone cyst.
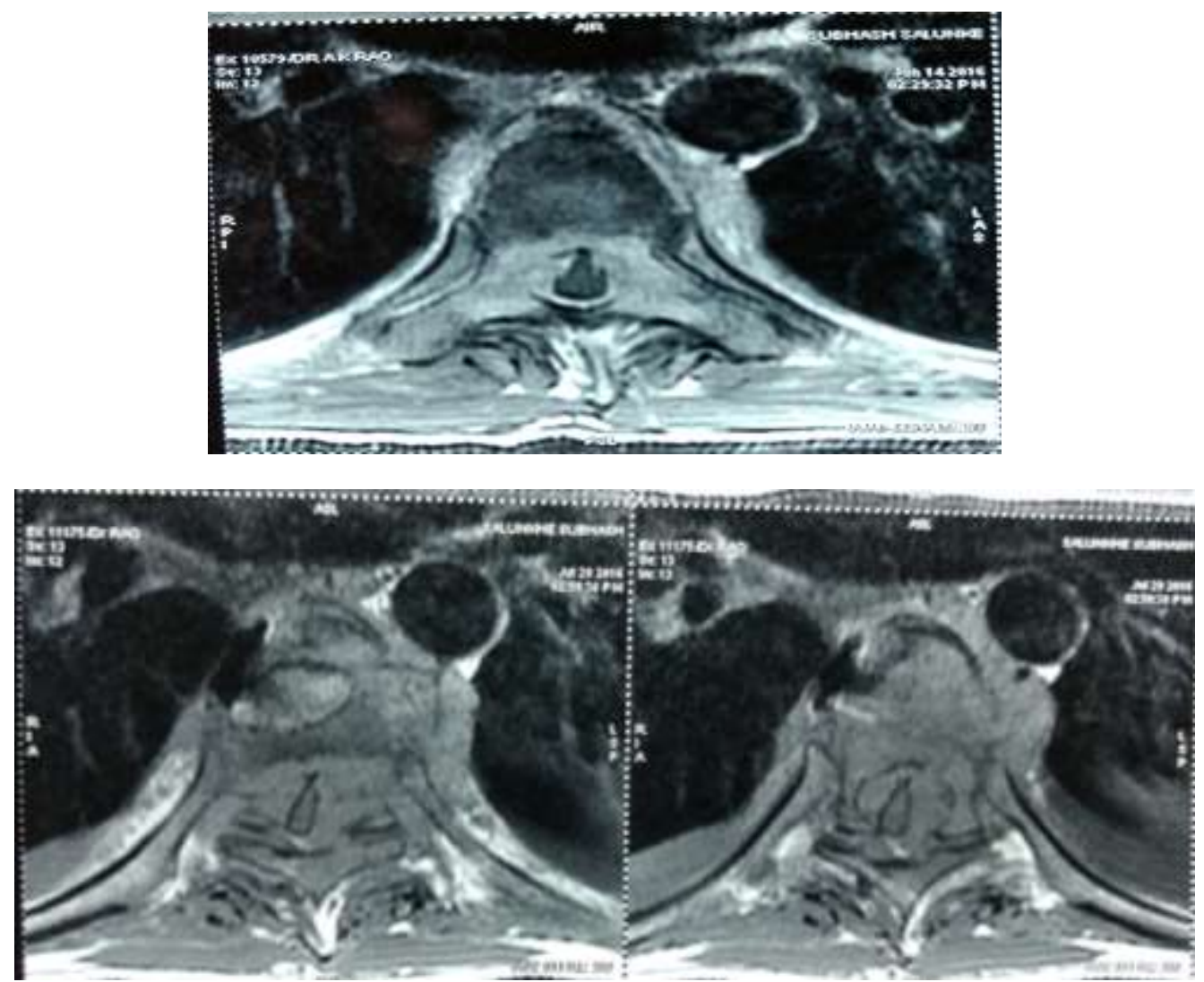

(a) Saggital T2 weighted magnetic resonance image showing tumor mass destroying seventh dorsal vertebral body leading to loss of height of the vertebra and extension into the spinal canal causing severe compression on the spinal cord,

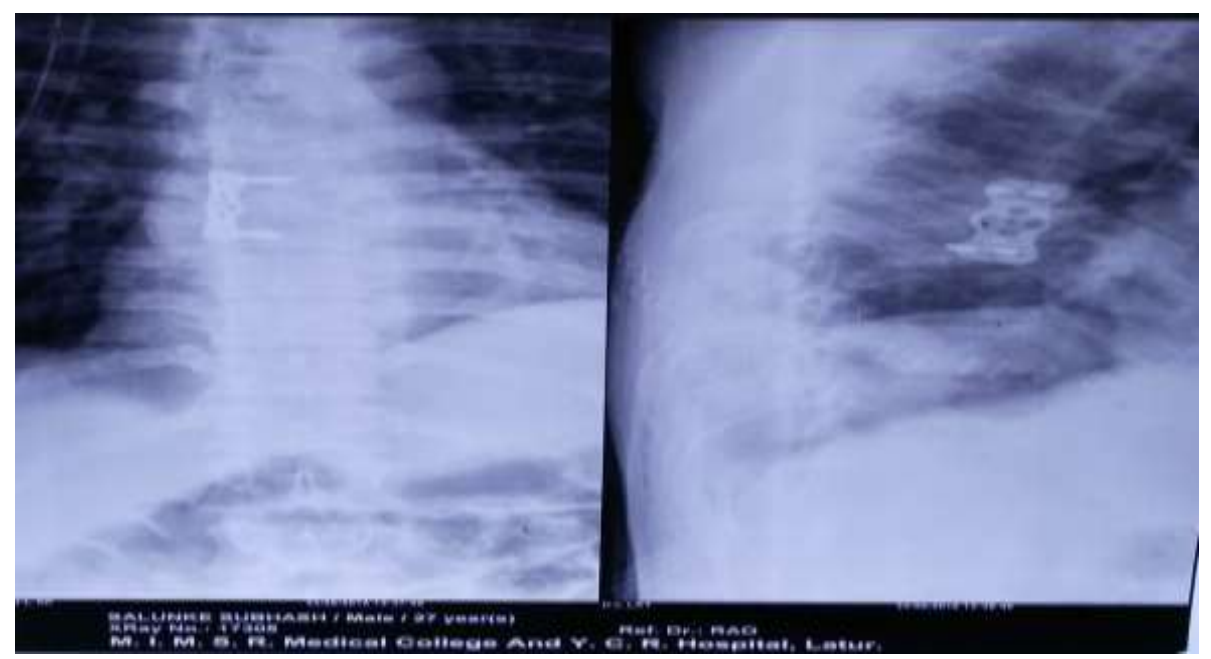

(b) Post-operative lateral $X$-ray image showing reconstruction using bone graft in place of excised tumor and titanium plate(b) Post-operative postero-anterior X-ray image with bone graft in place and plate and screws. 


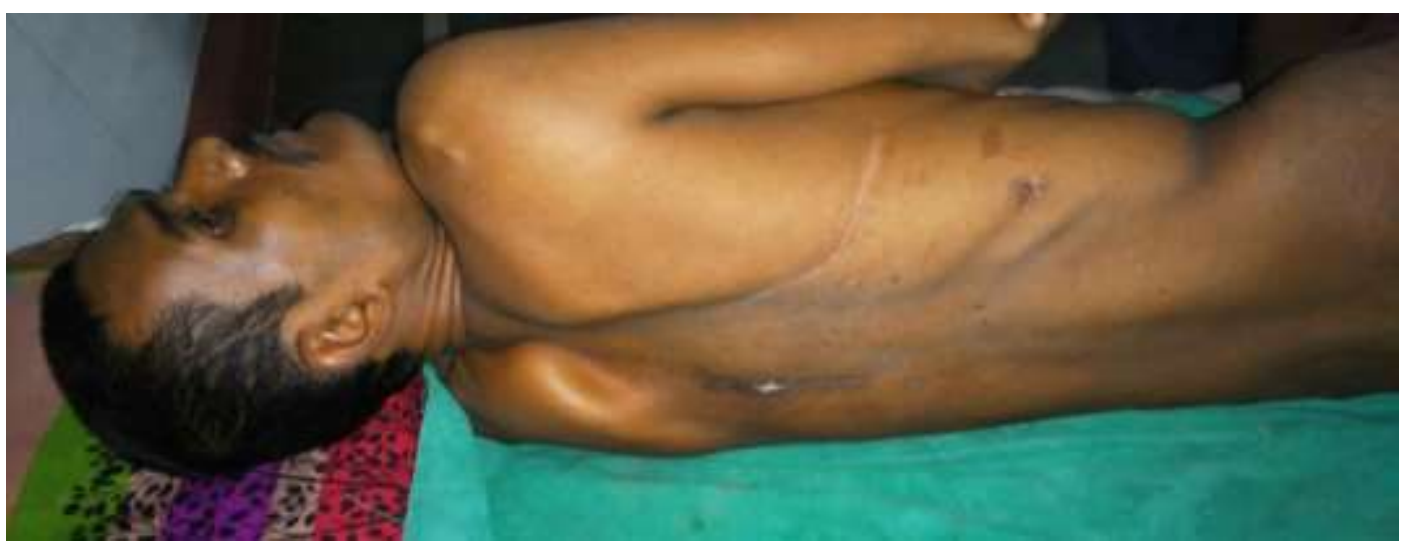

(c) post operative picture of patient with surgical scar mark which showing both scars at anterolateral and posterior side.

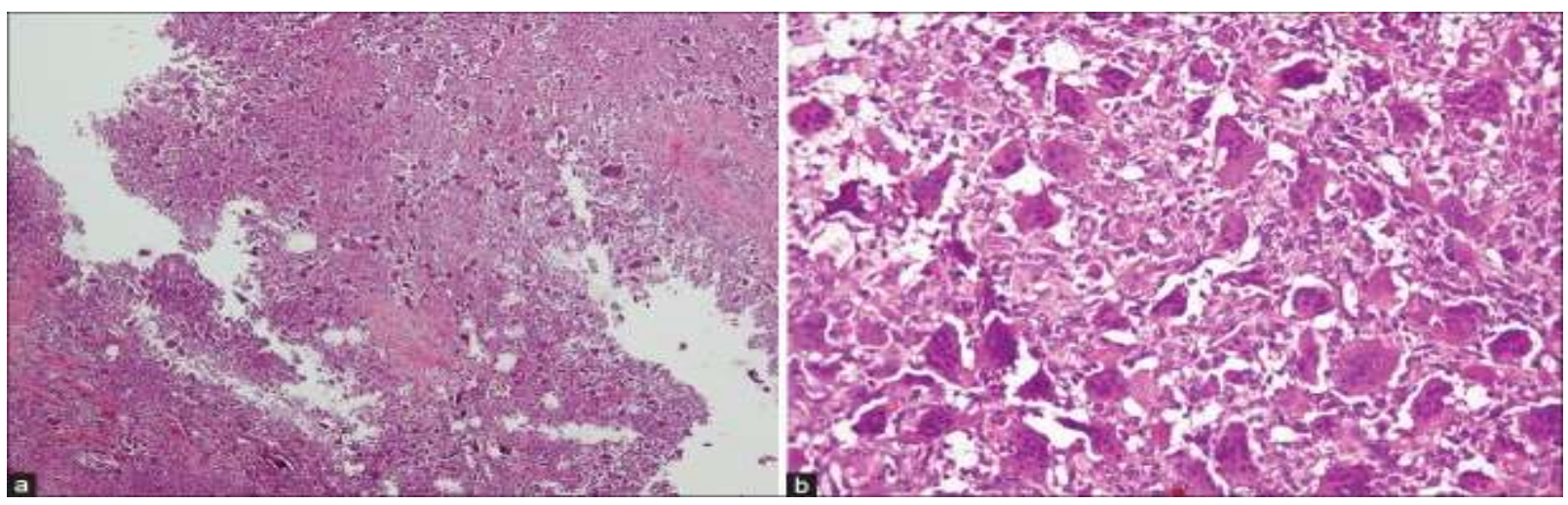

(d)Photomicrograph showing biphasic population of stromal cells and regularly scattered osteoclastic giant cells (H and E stain, $\times 10 \times 4)$, (b) Photomicrograph with higher magnification showing bland nuclear chromatin of the tumor cells.

\section{Discussion:-}

GCT of bone has incidence of 5\% among all primary bone tumors[1] and involvement of the mobile spinal segment is seen in only $1-1.5 \%$ of these cases. Roughly, equal incidence is seen in all three mobile spinal segments above the sacrum. It occurs in the age group of 20-45 with equal sex incidence.[2] Common symptoms include, back pain, neurological deficit due to compression of spinal cord, bladder and bowel dysfunction, and structural deformity of the spine.

The radiographic characteristics of spinal GCT are considered to be a round or oval extrapleural mass with shell-like calcification of the marginal lesion and the absence of a mineralized matrix. As opposed to other tumors they involve the vertebral body and soft-tissue involvement may be present. Most common site for so called "benign metastasis" is the lung. The histologic appearance of GCT is a uniform distribution of multinucleated giant cells against a background of round to spindle shaped mononuclear stromal cells. Enneking staging system is used to the plan treatment for GCTs. This classification system divides low grade tumors into stage 1 and high grade tumors into stage 2.

Various modalities of treatment are recommended for spinal GCTs such as surgery, radiotherapy, embolization, cryosurgery, cementation, and chemical adjuvant like phenol or liquid nitrogen. Total en bloc surgical excision is the treatment of choice in long bones as well as spine but is not always feasible in the spine due to the unacceptable risk of permanent neurological deficit.[3] Earlier adjuvant radiotherapy was thought to convert this low grade tumor into high grade malignant tumor with poor prognostic outcome, but with improved treatment protocols this is not the case.[4] However, due to the risk of myelitis and bone graft complications, it should be reserved for incomplete tumor excision and local recurrence. 
Close follow-up is required to detect recurrence of the tumor. Donthineni et al.[5] noted higher rate of lung metastases from GCT of the mobile spine as compared to long bones.Pulmonary metastases have been cited as the cause of death in 16-25\% of reported cases.Metastasectomy of lung nodules can be considered in view of prolonged survival. Plain radiograph of local site and chest are simple tools to look for any recurrent lesion. Periodic computed tomography and MRI are excellent tools to clearly identify the recurrent lesion and plan necessary treatment.

In the present case, total tumor excision was achieved by intralesional approach and solid reconstruction was achieved using titanium plate and screws. As total en-bloc excision could not be carried out, close follow-up is required for any sign of local and distant recurrence.

\section{References:-}

1. Mendenhall WM, Zlotecki RA, Scarborough MT, Gibbs CP, Mendenhall NP. Giant cell tumor of bone.Am J ClinOncol. 2006;29:96-9.

2. Campanacci M, Baldini N, Boriani S, Sudanese A. Giant-cell tumor of bone. J Bone Joint Surg Am.1987;69:106-14.

3. Boriani S, Weinstein JN, Biagini R. Primary bone tumors of the spine. Terminology and surgical staging.Spine (Phila Pa 1976) 1997;22:1036-44.

4. Fidler MW. Surgical treatment of giant cell tumours of the thoracic and lumbar spine: Report of nine patients. Eur Spine J. 2001;10:69-77.

5. Campanacci M, Baldini N, Boriani S. Giant-cell tumor of bone. J Bone Joint Surg Am. 1987 Jan. 69(1):106-14.

6. Dahlin DC, Cupps RE, Johnson EW Jr. Giant-cell tumor: a study of 195 cases. Cancer. 1970 May. 25(5):106170 .

7. Goldenberg RR, Campbell CJ, Bonfiglio M, et al. Giant-cell tumor of bone. An analysis of two hundred and eighteen cases. J Bone Joint Surg Am. 1970 Jun.

8. Hefti FL, Gachter A, Remagen W. Recurrent giant-cell tumor with metaplasia and malignant change, not associated with radiotherapy. A case report. J Bone Joint Surg Am. 1992 Jul. 74(6):930-4.

9. Mori Y, Tsuchiya H, Karita M. Malignant transformation of a giant cell tumor 25 years after initial treatment.ClinOrthop. 2000 Dec. (381):185-91.

10. Rock MG, Sim FH, Unni KK. Secondary malignant giant-cell tumor of bone. Clinicopathological assessment of nineteen patients. J Bone Joint Surg Am. 1986 Sep. 68(7):1073-9.

11. Donthineni R, Boriani L, Ofluoglu O, Bandiera S. Metastatic behaviour of giant cell tumour of the spine.IntOrthop. 2009;33:497-501.

12. Kay RM, Eckardt JJ, Seeger LL, et al. Pulmonary metastasis of benign giant cell tumor of bone. Six histologically confirmed cases, including one of spontaneous regression. ClinOrthop. 1994 May. (302):219-30.

13. Maloney WJ, Vaughan LM, Jones HH, et al. Benign metastasizing giant-cell tumor of bone. Report of three cases and review of the literature. ClinOrthop. 1989 Jun. (243):208-15.

14. Rock M. Adjuvant management of benign tumors; basic concepts of phenol and cement use. ChirOrgani Mov. 1990. 75(1 Suppl):195. 